\title{
The Financial Performance and Problems of Lending Investors
}

\author{
MARIANO M. LERIN \\ president_liceo@yahoo.com.ph \\ Liceo de Cagayan University
}

Dated Submitted: August 15, 2007

Final Revision Accepted: January 15, 2008

\begin{abstract}
This study investigated the financial performance and problems of lending investors in Region 10, Northern Mindanao. It used the descriptive survey method with researcher - made questionnaire for data gathering. The respondents were the managers and chief operating officers of the leading companies in Region 10. The data were analyzed using the percentage and chi-square. The study found that lending investors in Region 10 are profitable although some have low rates of return. The financial performances of lending investors in Region 10 vary significantly when grouped according to gender, civil status, and place of business. Lending institutions managed by males and married persons and located in capital cities and towns are more profitable than those managed by females and single persons and located in towns.
\end{abstract}

Key words - Financial performance, lending institutions

\section{INTRODUCTION}

Small businesses badly need financial sources for their operations. However, they are outright disqualified from credit accommodation due to criteria of banks and financing companies. They are bothered by the cumbersome documentation procedures and requirements and the delayed approval and release of the loan. Some businesses run to usurious money lenders who charge exorbitant interest rates. To assist small businesses, lending investors emerged in the eighties to serve the financial needs of small entrepreneurs, and to a certain extent, of the underground economy.

Central Bank Circular 205, Series of 1982 deregulated the lending rates effective January 1983 and allowed market forces to determine the interest rates. It virtually abolished the Usury Law and amended all previous legislated ceilings of loans. This was done to help lending investors sustain their operations and continue their services 
to small entrepreneurs.

Operationally, the lending investors are at a midpoint between formal money lenders (banks, financing companies) and informal money lenders. Their lending rates are higher than what the banks charge, but still less onerous than the rate of the informal money lenders. For the small borrower, it is not the cost of the credit that matters, but the availability and the timely delivery of credit. Since lending investor is in the business of lending money, it is categorized as a financial institution and its existence is subject to the authorization of Bangko Sentral ng Pilipinas. However, the BSP's supervision is minimal and is confined to requiring the submission of various operational and financial reports.

Lending investors are different from other financial institutions. There are banks (universal banks, commercial banks, development banks, thrift banks, rural banks), investment houses, and financing companies whose operations are defined by law. These institutions are defined as bank/non-bank financial intermediaries performing banking/ quasi banking functions. Aside from lending money, these institutions accept deposits from the public, issue commercial papers and securities, engage in financing and financial leasing, avail of Bangko Sentral ng Pilipinas, and perform such other functions as provided by the General Banking Act.

The lending investor is classified as a non-bank financial intermediary who does not perform quasi banking functions. It should be differentiated from banks, investment houses, and financing companies whose scopes of operations are larger. Bangko Sentral ng Pilipinas authorized lending investors to lend money to a host of borrowers and accept deposits at any one time. Lending investors are not required by Bangko Sentral ng Pilipinas legal reserve, which means lending out their borrowed funds at any point in time. But there is no financial assistance in terms of rediscounting facilities that can be secured by BSP. Deposits from individuals are not covered by the Philippine Deposit Insurance Corporation (PDIC).

The smallness of the lending investor in terms of capitalization and its limited scope of coverage work to its own advantage. The overhead expenses are low. The criterion used by lending investor in granting credit varies from borrower to borrower. While guided by a set of policies and procedures, selections depend to a large extent on the credit worthiness of the borrower. The lending investor exercises a wide range of flexibility that the bank manager, especially those stationed in big cities, does not apply.

Lending investors service the small entrepreneurs including those of the underground economy, a segment of financial market that the bank may not really be able to accommodate. The small entrepreneurs are in constant need of funds to support their ventures' very existence and the lending investors fill their credit gap. This business group is now growing and the potential of the lending investor is unimaginable. In an uncontrollable environment, there will always be as many lenders as there are borrowers.

Our economy needs small entrepreneurs to support the programs of government in alleviating poverty. Since these small entrepreneurs may not be able to meet the requirements of banks when they apply for loans, the role of lending investors cannot be overemphasized. Lending investors, to be able to sustain operations and continue their services to small businesses, need the support of all concerned. Addressing this problem becomes necessary. Findings of this study can help lending companies identifying solutions to improve their financial performance and minimize their lending problems. 


\section{FRAMEWORK}

The research areas of the study were the profile of the respondents and the lending companies' financial performance and problems encountered. The research process included the formulation and administration and retrieval of the questionnaires, tabulation of data, analysis and interpretation of data, and testing of the hypothesis. The findings were the bases for drawing conclusions and recommendations.

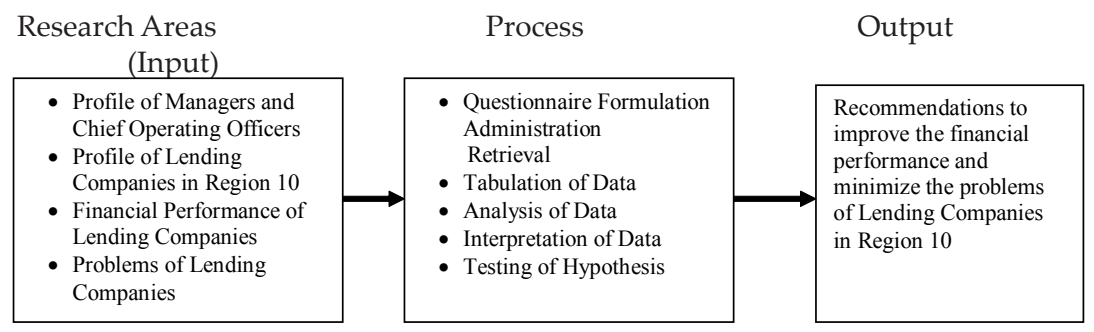

Figure 1. The Research Flow

\section{OBJECTIVES}

The study pursued the following objectives: (1.) to describe the profile of managers and chief operating officers; (2.) to characterize the lending companies in Region X; (3.) to determine the financial performance of lending companies; and, (4.) to identify the problems of lending companies.

\section{METHODOLOGY}

The study used the descriptive survey method with researcher-made questionnaire as tool for data gathering. The questionnaire was based on the manual of operations for lending investors developed by Central Bank of the Philippines in the early 90's and the amendments issued by the Bangko Sentral ng Pilipinas. This study was conducted in Region 10, Northern Mindanao. The region has five provinces: Bukidnon, Camiguin, Lanao del Norte, Misamis Occidental, and Misamis Oriental. To get good representations, about 50 percent of the respondents were spread among the five capitals of the five provinces and the remaining percentage was taken from the different towns of the five provinces in Region 10.

The respondents of the study were the managers and chief operating officers of the lending companies in Region 10. Few of the chief operating officers were the owners themselves, chairmen of the Board, members of the Board, and presidents and directors of lending companies.

The questionnaire was divided into five parts. Part I asked for the profile of the respondents (managers and chief operating officers), while Part II asked for the profile of the lending companies. Part III elicited information on the profitability of the lending company, while Part IV inquired into the problems encountered by the lending company. Part V asked for the respondents' recommendations to improve financial performance and minimize the problems of lending companies in Region 10. The 
questionnaires were distributed to the respondents. The questionnaires were retrieved after a month. The answers of the respondents were then tallied, tabled, analyzed, and interpreted.

Of the 100 questionnaires distributed to the different lending investors in the five provinces of Region 10, only 67 were retrieved. Some respondents either failed to accomplish the questionnaire or were not around when the questionnaire were distributed. Of the 67 questionnaires retrieved, only 50 were included since 17 questionnaires had inconsistent answers, not completely accomplished, or answered by lending companies that have existed for three years and below. The data collected were analyzed and interpreted using the percentage for the profile of the respondents and the lending companies and the financial performance (profitability) of the lending companies. Ranking was used for the problems encountered and the recommendations proposed to improve the financial performance and minimize the problems of lending companies. The Chi-Square was used to test the relationship of variables.

\section{RESULTS AND DISCUSSION}

\section{On Profile of Respondents}

Table 1. Ages of the managers and chief operating officers

\begin{tabular}{lccc}
\hline & Age & Number & Percentage \\
\hline Below 25 & & 2 & 4.0 \\
$26-30$ & 12 & 24.0 \\
$31-35$ & 10 & 20.0 \\
$36-40$ & 11 & 22.0 \\
$41-45$ & 4 & 8.0 \\
$46-50$ & & 3 & 6.0 \\
$51-55$ & 2 & 4.0 \\
$56-60$ & & 4 & 8.0 \\
$61-65$ & & 1 & 2.0 \\
Above 65 & Total & 1 & 2.0 \\
& & $\mathbf{5 0}$ & $\mathbf{1 0 0 . 0}$ \\
\hline
\end{tabular}

Table 1 shows the ages of the managers and chief operating officers of the lending companies. As revealed, a number of the respondents aged between 26 to 40 years old. This indicates that the managers and chief operating officers of the lending companies in Region 10 are relatively young.

Table 2. Gender, civil status and educational attainment of the managers and chief operating officers

\begin{tabular}{|c|c|c|}
\hline Gender & Number & Percentage \\
\hline Male & 25 & 50.0 \\
\hline Female & 25 & 50.0 \\
\hline $\begin{array}{c}\text { Total } \\
\text { Civil Status }\end{array}$ & 50 & 100.0 \\
\hline Single & 26 & 52.0 \\
\hline Married & 24 & 48.0 \\
\hline Total & 50 & 100.0 \\
\hline \multicolumn{3}{|c|}{ Educational Attainment } \\
\hline High School Graduate & 6 & 12.0 \\
\hline College Graduate & 42 & 84.0 \\
\hline Master & 2 & 4.0 \\
\hline Total & 50 & 100.0 \\
\hline
\end{tabular}


Table 2 shows the gender, civil status, and educational attainment of the managers and chief operating officers of the lending companies. On gender, the respondents were equally composed of males and females. As to civil status, more than half $(52 \%)$ of the respodents were single, while a sizable number of them $(48 \%)$ were married. As regards educational attainment, majority $(84 \%)$ of the respondents were college graduates. Only $12 \%$ were high school graduates and $4 \%$ had master's degree.

Table 3. Positions of the respondents

\begin{tabular}{lcc}
\hline Position & Number & Percentage \\
\hline Loan Officer & 11 & 22.0 \\
General Manager & 10 & 20.0 \\
Proprietor & 8 & 16.0 \\
Operations Manager & 5 & 10.0 \\
Cashier & 5 & 10.0 \\
Credit Officer & 3 & 6.0 \\
Chairman of the Board & 3 & 6.0 \\
President & 2 & 4.0 \\
Marketing Manager & 2 & 4.0 \\
Member of the Board $\quad$ Total & 1 & 2.0 \\
$\quad \mathbf{5 0}$ & $\mathbf{1 0 0 . 0}$ \\
\hline
\end{tabular}

Table 3 presents the delegated positions of the respondents in their respective lending companies in Region 10. Among the 50 respondents, $22 \%$ were loan officers; $20 \%$, general managers; $16 \%$, proprietors; $10 \%$, operation managers and cashiers; $6 \%$, credit officers and chairmen of the Board; $4 \%$, presidents and marketing managers; and $2 \%$, members of the board.

Table 4. Number of years in the company of the managers and chief operating officers

\begin{tabular}{|c|c|c|}
\hline Number of Years & Number & Percentage \\
\hline 3 and below & 5 & 10.0 \\
\hline $4-6$ & 8 & 16.0 \\
\hline $7-9$ & 10 & 20.0 \\
\hline $10-12$ & 9 & 18.0 \\
\hline $13-15$ & 8 & 16.0 \\
\hline $16-18$ & 4 & 8.0 \\
\hline $19-21$ & 3 & 6.0 \\
\hline $22-24$ & 1 & 2.0 \\
\hline $25-27$ & 1 & 2.0 \\
\hline $28-30$ & 0 & 0.0 \\
\hline More than 30 & 1 & 2.0 \\
\hline Total & 50 & 100.0 \\
\hline
\end{tabular}

Table 4 presents the number of years the respondents have worked in the lending companies. Among the respondents, 20\% have worked for 7 to 9 years; $18 \%$, 10-12 years; $16 \%$, 4 to 6 years; $8 \%, 13-15$ years; $8 \%, 16-18$ years; $6 \%, 19-21$ years; and $2 \%$, 22 to 24 and 25-27 years. The data show that only a few of the managers and chief operating officers have worked in the lending business for more than 20 years, while almost half of them have worked in the lending business for more than 10 years. The data show a fast turnover of managers and chief operating officers. 


\section{On profile of Lending Companies in Region 10}

Table 5. Place of business of lending companies in Region 10

\begin{tabular}{lcc}
\hline \multicolumn{1}{c}{ Address } & Number & Percentage \\
\hline \multicolumn{1}{c}{ Capital: } & & 18.0 \\
Cagayan de Oro & 9 & 12.0 \\
Iligan City & 6 & 8.0 \\
Malaybalay City & 4 & 6.0 \\
Mambajao & 3 & 10.0 \\
Ozamis City & 5 & $\mathbf{5 4 . 0}$ \\
\multicolumn{1}{c}{ Towns of: } & $\mathbf{2 7}$ & \\
Bukidnon & & 8.0 \\
Camiguin & 4 & 6.0 \\
Lanao del norte & 3 & 10.0 \\
Misamis Occidental & 5 & 12.0 \\
Misamis oriental & 6 & 10.0 \\
$\quad$ Total & 5 & $\mathbf{4 6 . 0}$ \\
\end{tabular}

Table 5 presents the place of business of the 50 lending companies. The capital and town of each of the five provinces in Region 10 were represented. Of the 50 lending companies, $54 \%$ are situated in the capital of the five provinces, while $46 \%$ are in towns of the five provinces. Cagayan de Oro, being the biggest capital, had 9 lending companies, followed by Iligan City with 6, Ozamis City with 5, Malaybalay with 4, and Mambajao with 3. Among the towns, 6 were from the Province of Misamis Occidental, 5 from Lanao del Norte and Misamis Oriental, 4 from Bukidnon, and 3 from the Province of Camiguin.

Table 6. Form of business organization and year of established

\begin{tabular}{lcc}
\hline \multicolumn{1}{c}{ Business form } & Number & Percentage \\
\hline Single Proprietorship & 22 & 44.0 \\
Corporation & 21 & 42.0 \\
Cooperative & 7 & 14.0 \\
$\quad$ Total & $\mathbf{5 0}$ & $\mathbf{1 0 0 . 0}$ \\
$\quad$ Year opened & & \\
$2000-2003$ & 6 & 12.0 \\
$1997-1999$ & 8 & 16.0 \\
$1994-1996$ & 7 & 14.0 \\
$1991-1993$ & 8 & 16.0 \\
$1988-1990$ & 9 & 18.0 \\
$1985-1987$ & 3 & 6.0 \\
$1982-1984$ & 2 & 4.0 \\
$1979-1981$ & 3 & 6.0 \\
$1976-1978 \quad 2$ & 2 & 4.0 \\
1975 and earlier & 2 & 4.0 \\
$\quad$ Total & $\mathbf{5 0}$ & $\mathbf{1 0 0 . 0}$ \\
\hline
\end{tabular}

Table 6 shows the lending companies' form of business organization and the year of establishment. As to the form of business, $44 \%$ are single proprietorship; $42 \%$, corporations; and 14\%, cooperative. As to the year established, a greater number of the lending companies (58\%) opened between 1991 to 2003. Those lending firms that opened between 2004 to 2006 were not included because their financial performance could not be ascertained yet. Besides, only few lending firms were opened during this 
period. While most of the businesses were opened between 1991 to the present, lending firms have existed even earlier than 1975, this inspite of the existence of banks and finance companies.

Table 7. Number of employees of lending companies

\begin{tabular}{ccc}
\hline Employees & Number & Percentage \\
\hline 1 & 2 & 4.0 \\
2 & 5 & 10.0 \\
3 & 7 & 14.0 \\
4 & 6 & 12.0 \\
5 & 6 & 12.0 \\
6 & 4 & 8.0 \\
7 & 5 & 10.0 \\
8 & 4 & 8.0 \\
9 & 3 & 6.0 \\
10 & 2 & 4.0 \\
More than 10 & 6 & 12.0 \\
Total & $\mathbf{5 0}$ & $\mathbf{1 0 0 . 0}$ \\
\hline
\end{tabular}

Table 7 presents the number of employees the main offices and branches of the lending companies have. Of the 50 lending companies, 14\% employed 3 employees; $12 \%, 4$ and 5 and more than 10 employees; $10 \%, 2$ and 7 employees; $8 \%, 6$ and 9 employees; 6\%, 9 employees; and 4\%, 1 and 10 employees. The six lending companies that employed more than 10 persons have the biggest capital and the highest number of branches. Lending investors with small capital employ only one or two employees.

Table 8. Number of branches of lending companies

\begin{tabular}{ccc}
\hline Number of Branches & Number & Percentage \\
\hline 0 & 8 & 16.0 \\
1 & 7 & 14.0 \\
2 & 6 & 12.0 \\
3 & 8 & 16.0 \\
4 & 5 & 10.0 \\
5 & 3 & 6.0 \\
6 & 4 & 8.0 \\
7 & 1 & 2.0 \\
8 & 2 & 4.0 \\
9 & 1 & 2.0 \\
10 & 1 & 2.0 \\
More than 10 & 4 & 8.0 \\
Total & $\mathbf{5 0}$ & $\mathbf{1 0 0 . 0}$ \\
\hline
\end{tabular}

The number of branches of the 50 lending companies is shown in Table 8. Eight lending investors do not have any branch. Most of these are of single proprietorship managed by the owners themselves. Seven of the lending companies have only one branch, six with two branches, eight with three, five with four, and three with five. There are four lending companies with six branches and two with eight branches. Lending companies with bigger capital have eight, nine, and ten branches. Four of the lending companies have more than ten branches. With number of branches as basis in determining the size of lending companies, these companies in Region 10 cannot be considered of big scale since majority $(68 \%)$ have less than five branches. The number 
Liceo Journal of Higher Education Research

of branches normally depends on the size of capital. Since many of these investors do not have very big capital, the number of branches is limited.

\section{On Financial Performance of Lending Companies}

Table 9. Starting capital of the lending companies

\begin{tabular}{lcc}
\hline \multicolumn{1}{c}{ Amount } & Number & Percentage \\
\hline Below P100,000 & 5 & 10.0 \\
P100,000-250,000 & 16 & 32.0 \\
$200,001-500,000$ & 8 & 16.0 \\
$500,001-750,000$ & 6 & 12.0 \\
$750,001-1,000,000$ & 3 & 6.0 \\
$1,000,001-2,000,000$ & 2 & 4.0 \\
$2,000,001-3,000,000$ & 1 & 2.0 \\
$3,000,001-4,000,000$ & 1 & 2.0 \\
$4,000,001-5,000,000$ & 1 & 2.0 \\
$5,000,001-10,000,000$ & 2 & 4.0 \\
$10,000,001-25,000,000$ & 1 & 2.0 \\
$25,000,001-50,000,000$ & 0 & 0.0 \\
More than $50,000,000$ & 1 & 2.0 \\
No answer & 3 & 6.0 \\
Total & 50 & 100.0 \\
\hline
\end{tabular}

Table 9 shows the starting capital of the lending companies. Five started the business with less than P100,000. These were the companies that opened when Central Bank now Bangko Sentral ng Pilipinas, had not yet prescribed the minimum capital requirement. The biggest number of the lending companies (32\%) had a capital of P100,000 to P250,000, followed by those lending companies with a capital of P20,001 to P500,000 (16\%), P500,001 to P750,000 (12\%), and P750,001 to P1,000,000 (6\%). These lending companies opened when Central Bank had started prescribing the minimum starting capital of at least P100,000. One of the lending companies started with more than P50,000,000. Three lending companies did not reveal their starting capital.

Table 10. Present capitalization

\begin{tabular}{lcc}
\hline Amount & Number & Percentage \\
\hline Below P500,000 & 5 & 10.0 \\
P500,000-P1,000,000 & 9 & 18.0 \\
$1,000,001-2,500,000$ & 10 & 20.0 \\
$2,500,001-5,000,000$ & 8 & 16.0 \\
$5,000,001-10,000,000$ & 4 & 8.0 \\
$10,000,001-20,000,000$ & 5 & 10.0 \\
$20,000,001-30,000,000$ & 1 & 2.0 \\
$30,000,001-40,000,000$ & 2 & 4.0 \\
$40,000,001-50,000,000$ & 0 & 0.0 \\
$50,000,001-75,000,000$ & 1 & 2.0 \\
$75,000,001-100,000,000$ & 0 & 0.0 \\
More than $100,000,000$ & 1 & 2.0 \\
No answer & 4 & 8.0 \\
Total & $\mathbf{5 0}$ & $\mathbf{1 0 0 . 0}$ \\
\hline
\end{tabular}


The present capital of the lending companies is shown in Table 10. Ten percent of the lending companies have a present capital of less than P500,000, $18 \%$ with $\mathrm{P} 500,000$ to $\mathrm{P} 1,000,000,20 \%$ with $\mathrm{P} 1,000,001$ to $\mathrm{P} 2,500,000$, and $16 \%$ with $\mathrm{P} 2,500,001$ to $\mathrm{P} 5,000,000$. Further, $8 \%$ have a present capital of $\mathrm{P} 5,000,001$ to $\mathrm{P} 10,000,000$ and $10 \%$ with a capital of $\mathrm{P} 10,000,001$ to $\mathrm{P} 20,000,000$. Only one lending company has a capital of more than P100,000,000, which is the biggest capital invested. The second biggest capital of $\mathrm{P} 50,000,001$ to $75,000,000$ is invested by another lending company.

The capital of P 5,000,000 and below invested by two-thirds of the lending companies needs to be increased. Additional capital can be raised through loans from banks and other financial institutions or private individuals.

Table 11. Amount of loans released per annum

\begin{tabular}{lcc}
\hline \multicolumn{1}{c}{ Amount } & Number & Percentage \\
\hline Below P500,000 & 18 & 36.0 \\
P500,000-1,000,000 & 12 & 24.0 \\
$1,000,001-2,500,000$ & 7 & 14.0 \\
$2,500,001-5,000,000$ & 5 & 10.0 \\
$5,000,001-10,000,000$ & 2 & 4.0 \\
$10,000,001-20,000,000$ & 1 & 2.0 \\
$20,000,001-30,000,000$ & 1 & 2.0 \\
$30,000,001-40,000,000$ & 0 & 0.0 \\
$40,000,001-50,000,000$ & 0 & 0.0 \\
$50,000,001-75,000,000$ & 0 & 0.0 \\
$75,000,001-100,000,000$ & 0 & 0.0 \\
More than $100,000,000$ & 1 & 2.0 \\
No answer & 3 & 6.0 \\
& $\mathbf{5 0}$ & $\mathbf{1 0 0 . 0}$ \\
\hline
\end{tabular}

Table 11 presents the amount of loans released per annum. Thirty-six percent of the lending companies released loans less than P500,000 per annum, the smallest amount released. This was followed by $24 \%$ of the lending companies that released loans amounting to P500,000 to P1,000,000 per annum, $14 \%$ that released $\mathrm{P} 1,000,001$ to $\mathrm{P} 2,500,000$ per annum, $10 \%$ that released $\mathrm{P} 2,500,001$ to $\mathrm{P} 5,000,000$, and $4 \%$ that released $\mathrm{P} 5,000,001$ to $\mathrm{P} 10,000,000$ per annum. Two percent released loans amounting to P10,000,001 to P20,000,000, P 20,000,001 to P30,000,000, and more than P100,000,000. Three lending companies did not reveal the amount of loans released per annum.

Table 12. Ages of loan receivables

\begin{tabular}{ccc}
\hline Days old & Number & Percentage \\
\hline $31-60$ days & 3 & 6.0 \\
$61-90$ & 2 & 4.0 \\
$91-120$ & 1 & 2.0 \\
$121-150$ & 3 & 6.0 \\
$151-180$ & 2 & 4.0 \\
$181-210$ & 2 & 4.0 \\
$211-240$ & 2 & 4.0 \\
$241-270$ & 1 & 2.0 \\
$271-300$ & 1 & 2.0 \\
$301-330$ & 2 & 4.0 \\
$331-366$ & 2 & 4.0 \\
More than one year & 4 & 8.0 \\
More than two years & 6 & 12.0 \\
More than three years & 12 & 24.0 \\
Did not answer & 7 & 14.0 \\
Total & $\mathbf{5 0}$ & $\mathbf{1 0 0 . 0}$
\end{tabular}


Table 12 shows the lending companies' ages of loan receivable. While some have loan receivables of less than 120 days old, 8 percent of the lending companies have loans receivable of more than one year. Twelve percent of the lending companies have very old loan receivables of more than two years old and 24 percent with loan receivables of more than three years.

The data show that the lending companies either do not have strict credit investigation of borrowers or do not have an efficient system of collections. The lending investors opted to keep the receivables instead of writing them off hoping that these receivables can still be collected.

Table 13. Average percentage of loan receivables written off per annum

\begin{tabular}{ccc}
\hline Average Percentage & Number & Percentage \\
\hline 0 & 2 & 4.0 \\
1 & 4 & 8.0 \\
2 & 7 & 14.0 \\
3 & 3 & 6.0 \\
4 & 6 & 12.0 \\
5 & 8 & 16.0 \\
6 & 2 & 4.0 \\
7 & 2 & 4.0 \\
8 & 1 & 2.0 \\
9 & 2 & 4.0 \\
10 & 3 & 6.0 \\
More than 10 & 5 & 10.0 \\
Did not answer & 5 & 10.0 \\
Total & $\mathbf{5 0}$ & $\mathbf{1 0 0 . 0}$ \\
\hline
\end{tabular}

The average percentage of loan receivables written off per annum is presented in Table 13. Some have good collections considering that only 1 percent of the receivables were written off by four lending companies, 2 percent by seven, and 3 percent by three. Three lending companies wrote off 5 percent of the receivables, three write off 10 percent, and five wrote off more than 10 percent. Five lending companies did not reveal the percentage of receivables written off. These figures show that collections are poor and the granting of loan does not pass rigid procedures. Writing off more than 10 percent of the receivables is very alarming; hence, lending companies must improve their collection strategies to minimize receivables of old accounts.

Table 14. Interest rates charged per month

\begin{tabular}{cccc}
\hline Rate & Number & Percentage \\
\hline 1 & 4 & 8.0 \\
2 & 8 & 16.0 \\
2.5 & 3 & 6.0 \\
3 & 8 & 16.0 \\
4 & 5 & 10.0 \\
5 & 6 & 12.0 \\
6 & 3 & 6.0 \\
7 & 2 & 4.0 \\
8 & 1 & 2.0 \\
9 & 0 & 0.0 \\
& 2 & 4.0 \\
& 10 & 2 & 4.0 \\
& More than 10 & 6 & 12.0 \\
Total & No answer & $\mathbf{5 0}$ & $\mathbf{1 0 0 . 0}$ \\
\hline
\end{tabular}


Shown in Table 14 are the different interest rates charged by lending companies to their clients or borrowers. Only 8 percent of the lending companies charged a minimal rate of 1 percent per month or 12 percent per annum. Sixteen percent charged 2 percent interest rate and 6 percent charged 2.5 percent interest rate. Two-thirds of the lending companies $(68 \%)$ charged an interest rate of 5 percent and below per month. Four percent of the lending companies charged an interest rate of 10 percent and more per month. Since Bangko Sentral ng Pilipinas does not anymore put a cap on interest rates, some lending companies charge even more than 10 percent interest rate per month or 120 percent per annum. However, most lending companies do not charge with high interest rates because banks charge borrowers with much lower rates.

Table 15. Percentage of profit to equity of lending companies

\begin{tabular}{ccc}
\hline Rate of Profit & Number & Percentage \\
\hline $1-2$ & 4 & 8.0 \\
$3-4$ & 4 & 8.0 \\
$5-6$ & 7 & 14.0 \\
$7-8$ & 5 & 10.0 \\
$9-10$ & 6 & 12.0 \\
$11-12$ & 3 & 6.0 \\
$13-14$ & 3 & 6.0 \\
$15-16$ & 4 & 8.0 \\
$17-18$ & 2 & 4.0 \\
$19-20$ & 3 & 6.0 \\
More than 20 & 2 & 4.0 \\
No answer & 7 & 14.0 \\
Total & $\mathbf{5 0}$ & $\mathbf{1 0 0 . 0}$ \\
\hline
\end{tabular}

The percentage of profit of investment of lending investors is shown in Table 15. Only 8 percent of the lending companies earned 1 to 2 percent and 3 to 4 percent profit and 14 percent earned 5 to 6 percent profit. Ten percent of the lending companies earned 7 to 8 percent profit, while the rest of the lending companies earned 9 percent to more than 20 percent profit, which are above the existing rates of returns of most business entities in the Philippines. In general, lending companies in Region 10 are earning well. An earning of less than 8 percent is very conservative. Hence, lending companies with such rate of profit should operate better to improve profitability and sustain the operation.

Table 16. Profitability of lending investors classified according to gender of managers and chief operating officers

\begin{tabular}{lcccccc}
\hline \multicolumn{1}{c}{ Profit } & \multicolumn{2}{c}{ GENDER } & \multicolumn{2}{c}{ CIVIL STATUS } & \multicolumn{2}{c}{$\begin{array}{c}\text { PLACE OF } \\
\text { BUSINESS }\end{array}$} \\
\hline & Male & Female & Single & Married & Capital & Towns \\
Below P50,000 & 5.87 & 5.42 & 6.54 & 5.69 & 5.95 & 5.60 \\
P50,000-100,000 & 6.12 & 5.66 & 6.13 & 6.23 & 6.36 & 6.21 \\
$100,001-200,000$ & 6.02 & 5.99 & 6.24 & 6.33 & 6.00 & 6.17 \\
$200,001-300,000$ & 6.41 & 6.00 & 6.20 & 6.28 & 6.56 & 5.99 \\
$300,001-400,000$ & 5.99 & 5.97 & 6.09 & 6.10 & 6.00 & 5.98 \\
$400,001-500,000$ & 6.00 & 5.99 & 6.03 & 6.04 & 6.02 & 6.01 \\
$500,001-600,000$ & 6.08 & 6.03 & - & 5.99 & 5.99 & 5.98 \\
$600,001-700,000$ & - & 6.01 & 6.03 & - & 6.03 & 6.03 \\
$700,001-800,000$ & 6.10 & - & 6.11 & - & 6.13 & - \\
$900,001-1,000,000$ & 5.98 & 5.89 & 5.98 & - & 6.11 & 6.00 \\
$1,000,001-2,000,000$ & 6.15 & 6.05 & 6.14 & 6.03 & 6.45 & 6.12 \\
2,000,001-3,000,000 & - & 5.97 & 5.99 & 6.04 & 6.03 & - \\
P 50,000,000 & 6.01 & - & 6.03 & 6.06 & 6.02 & 6.00 \\
More than P50,000,000 & 6.04 & - & - & 5.98 & 6.04 & - \\
Total & $\mathbf{6 . 5 6}$ & $\mathbf{5 . 4 2}$ & $\mathbf{6 . 5 4}$ & $\mathbf{5 . 6 9}$ & $\mathbf{6 . 9 5}$ & $\mathbf{4 . 6 0}$ \\
\hline
\end{tabular}


Table 16 presents the profitability of lending investors when classified according to gender of managers and chief operating officers. Four of the investors made profit of not less than P50,000; five, P50,000 to P100,000; five,P100,001 to P200,000; five, P200,001 to $\mathrm{P} 300,000$. The biggest income of more than P50,000,000 was earned by a male manager. The data show that not one of the 50 lending investors lost profit in the past three years. Classified according to gender of managers, lending investors managed by males were more profitable than those managed by females.

Table 17. Profitability of lending investors classified according to civil status of managers and chief operating officers

\begin{tabular}{lcccc}
\hline \multicolumn{1}{c}{ Profit } & Number & Percentage & $\begin{array}{c}\text { Civil Status of Managers / Chief } \\
\text { Operating Officers } \\
\text { Single }\end{array}$ \\
Below P50,000 & & & 2 & 2 \\
P50,000-100,000 & 4 & 8.0 & 2 & 3 \\
$100,001-200,000$ & 5 & 10.0 & 2 & 3 \\
$200,001-300,000$ & 5 & 10.0 & 2 & 3 \\
$300,001-400,000$ & 5 & 10.0 & 1 & 1 \\
$400,001-500,000$ & 2 & 4.0 & 1 & 1 \\
$500,001-600,000$ & 2 & 4.0 & 0 & 2 \\
$600,001-700,000$ & 2 & 4.0 & 2 & 0 \\
$700,001-800,000$ & 2 & 4.0 & 1 & 0 \\
$800,001-900,000$ & 1 & 2.0 & 0 & 0 \\
$900,001-1,000,000$ & 0 & 0.0 & 2 & 2 \\
$1,000,001-2,000,000$ & 2 & 4.0 & 1 & 1 \\
$2,000,001-3,000,000$ & 4 & 8.0 & 0 & 0 \\
3,000,001-4,000,000 & 2 & 4.0 & 0 & 4 \\
More than P50,000,000 & 0 & 0.0 & 9 & 24 \\
No answer & 1 & 2.0 & 26 & \\
Total & 13 & 26.0 & 2 & \\
\hline
\end{tabular}

Table 17 shows the profitability of lending investors when classified according to civil status of the managers and chief operating officers. The highest income of more than P50,000,000 was earned by a married manager or chief operating officer. The income of P1,000,001 to P2,000,000 and P2,000,001 to P3,000,000 were equally earned by both single and married managers. There were 13 investors who did not reveal their income. The data reveal that lending companies run by married managers and chief operating officers were more profitable than those runby singleones ones.

Table 18. Profitability of lending investors classified according to place of business

\begin{tabular}{lcccc}
\hline \multicolumn{1}{c}{ Profit } & Number & Percentage & \multicolumn{2}{c}{ Place of Business } \\
\hline Below P50,000 & 4 & & Capital & Towns \\
P50,000-100,000 & 5 & 8.0 & 1 & 3 \\
$100,001-200,000$ & 5 & 10.0 & 3 & 2 \\
$200,001-300,000$ & 5 & 10.0 & 2 & 1 \\
$300,001-400,000$ & 2 & 10.0 & 4 & 1 \\
$400,001-500,000$ & 2 & 4.0 & 1 & 1 \\
$500,001-600,000$ & 2 & 4.0 & 1 & 1 \\
$600,001-700,000$ & 2 & 4.0 & 1 & 0 \\
$700,001-800,000$ & 1 & 4.0 & 1 & 0 \\
$800,001-900,000$ & 0 & 2.0 & 0 & 1 \\
$900,001-1,000,000$ & 2 & 0.0 & 1 & 1 \\
$1,000,001-2,000,000$ & 4 & 4.0 & 3 & 0 \\
$2,000,001-3,000,000$ & 2 & 8.0 & 2 & 0 \\
$3,000,001-4,000,000$ & 0 & 4.0 & 0 & 8 \\
More than P 50,000,000 & 1 & 0.0 & 1 & $\mathbf{2 3}$ \\
No answer & 13 & 2.0 & $\mathbf{2 7}$ & \\
Total & $\mathbf{5 0}$ & $\mathbf{1 0 0 . 0}$ & & 0 \\
\hline
\end{tabular}


Presented in table 18 is the profitability of lending investors when classified according to place of operation. The smallest income of less than P50,000 was earned by one investor located in the capital of the province and three by investors located in the different towns of the province. The biggest income of P2,000,001 to P3,000,000 and more than P50,000,000 were earned by lending investors operating in the capitals of the provinces. Classified according to places of operations, lending investors operating in capital cities and towns of Region 10 were more profitable than those in towns.

\section{On relationship among profit, and gender, civil status, place of business, and profit}

Table 19. Test of relationship among profit, gender, civil status, place of business, and profit

\begin{tabular}{lcccccc}
\hline Profile & $\begin{array}{c}\text { Chi-Square } \\
\text { Calculated } \\
\text { Value }\end{array}$ & $\begin{array}{c}\text { Degrees of } \\
\text { Freedom }\end{array}$ & $\begin{array}{c}\text { Chi- } \\
\text { Square } \\
\text { Critical } \\
\text { (Table) } \\
\text { Value }\end{array}$ & Significance & Interpretation & $\begin{array}{c}\text { Decision on } \\
\text { Ho: }\end{array}$ \\
\hline Gender & 67.23958 & 26 & 43.77 & .00002 & Significant & Reject \\
Civil Status & 60.90774 & 26 & 43.77 & .00013 & Significant & Reject \\
Place of & 59.63636 & 26 & 43.77 & .00019 & Significant & Reject \\
Business & & & & & & \\
\hline
\end{tabular}

Table 19 shows the test of relationship among profit, gender, civil status, and place of business. As shown in the table, gender had the highest Chi-Square value of 67.23958 at .00002 level of significance; civil status, 60.90774; and place of business with 59.63636. The figures show that there was an existing significant relationship among the variables. Lending companies run by males and married managers and operating in capital cities and towns are more profitable than those run by females and singles and operating in towns.

\section{On Problems encountered by lending investors in Region 10}

Table 20. Problems of lending investors (Multiple answers)

\begin{tabular}{lcc}
\hline \multicolumn{1}{c}{ Problems } & Frequency & Rank \\
\hline Delinquent Borrowers & 45 & 1 \\
Bounching checks & 38 & 2 \\
Lack of collateral & 32 & 3 \\
Low interest rate due to & 31 & 4 \\
$\quad$ competition & 28 & 5 \\
Decreased borrowing due to low $\quad$ & \\
banks rate. & 27 & 6 \\
High rental of office space & 26 & 7 \\
Unfriendly and uncooperative & & \\
$\quad$ lending investors & 22 & 8 \\
Strict government laws & 1 & 9 \\
High taxes imposed & 18 & 10 \\
Increasing salary rate due to & & \\
$\quad$ tripartite board decision & 10 & 11 \\
Absentism and non-punctuality of & & \\
$\quad$ employees & 8 & 12 \\
Other problems & 7 & 13 \\
Double mortgage of collateral & 6 & 14 \\
Shortage of collection & 5 & 15 \\
Disappearing borrowers & 3 & 16 \\
Lack of capital & 3 & 17 \\
Suinde robbery & 3 & 18 \\
Dishonest employees & 3 & 19 \\
Dishonest borrowers & 2 & 20 \\
Competition with other lenders & & \\
Multiple loans of borrowers & &
\end{tabular}


Table 20 presents the problems commonly met by lending investors in region 10. Among the problems identified by the lending investors, collaterals not existing when loans become due as the third problem which was pointed delinguent borrowers ranked first followed by bounching checks (2), lack of collateral (3), low interest rate due to competition (4), and low borrowing rate (5). Other problems cited included: high rental of office space (6), unfriendly and uncooperative lending investors (7), strict government laws (8), high taxes imposed (9), and employees' demand for higher salary (10).

Table 21 shows the recommendations of lending investors to improve the financial performance of the business and minimize the problems. Presented are only those recommended by three investors. The top five recommendations were: thorough credit investigation of business, strengthened collection strategies, improved collection techniques of past due accounts, properly controlled loan releases, and properly monitored loan receivables. Other recommendations worth noting included developing excellent marketing strategies, designing attractive loan terms, creating better relationship with banks, working with other lending investors for uniform interest rates of loans, and making borrowing requirements easier to be complied by borrowers.

\section{Recommendations advanced to improve the performance of lending investors in Region 10}

Table 21. Respondents' recommendation to improve the financial performance and minimize the problems of lending investors in region 10 (Multiple answer)

\begin{tabular}{lcc}
\hline \multicolumn{1}{c}{ Quality credit investigation of borrowers } & Frequency & Rank \\
\hline \multicolumn{1}{c}{ Strengthen collection strategies } & 43 & 1 \\
Improve collection techniques of past due accounts & 40 & 2 \\
Control loan releases & 39 & 3 \\
Monitor amounts of receivable & 38 & 4 \\
Apply excellent marketing strategies & 32 & 5 \\
Design attractive loan terms & 29 & 6 \\
Create better relationships with banks & 28 & 7 \\
Work with other lending investors for a uniform interest rates of loans & 22 & 8 \\
Make requirements easy to comply by borrowers & 20 & 9 \\
Implement abstract or truth in lending & 19 & 10 \\
Strictly follow BSP circulars & 12 & 11 \\
Performance be given to loans with productive purposes & 16 & 12 \\
Implement strictly insurance coverage & 14 & 13 \\
Exchange loan data with other lending investors & 13 & 14 \\
Seek endorsement assistance & 12 & 15 \\
Implement strict cash flow procedure & 11 & 16 \\
Place security guards during and after office hours & 8 & 17 \\
Insure Collection & 6 & 18 \\
Exchange information on bad borrowers & 5 & 19 \\
Check on employees's punctuality & 4 & 20 \\
Updates policies systems and procedures regularly. & 3 & 21 \\
\hline
\end{tabular}




\section{CONCLUSIONS} return.

Lending investors in Region 10 are profitable although some have low rates of

The financial performances of lending investors in Region 10 vary significantly when grouped according to gender and civil status of the respondents and place of business of the investors.

Lending investors managed by males and married persons, and those located in capital cities and towns are more profitable than those managed by females, by single persons, and those located in towns.

\section{LITERATURE CITED}

\section{Bangko ng Pilipinas Circulars}

BSP Circular No. 291, Amendment to the provisions of the manual of regulation for banks and non-banks financial institutions.

Central Bank Circular 205, Series of 1982

Manual of Accounts for Lending Investors.

Manual of Operations for Lending Investors. 